\title{
Ergonomic Conditions and Health at Gender Segregated Workplaces
}

\author{
Lena Karlqvist ${ }^{*}, 1$ and Gunvor Gard ${ }^{1,2}$ \\ ${ }^{I}$ Department of Health Sciences, Luleå University of Technology, SE-971 87 Luleå, Sweden \\ ${ }^{2}$ Department of Health Sciences, Lund University Hospital, SE-221 85 Lund, Sweden
}

\begin{abstract}
Purpose: To investigate working conditions and health at gender segregated (most women, $\geq 60 \%$ women or most men, $\geq 60 \%$ men) workplaces with a focus on associations of ergonomic exposures with musculoskeletal disorders.

Methods: A comprehensive questionnaire was randomly sent to 10000 inhabitants in three municipalities in the middle of Sweden. The response rate was 50\% (4965 men and women). Organisational, physical and psychosocial working conditions and the musculoskeletal symptom panorama as well as general health and psychological well-being were compared between men and women in the gender segregated workplaces.

Results: There were significant differences in working conditions between men and women both in female and male dominated workplaces. Most differences concerned physical work environment factors at both workplaces. However, the level of low control and strain were more prevalent among women in male dominated workplaces. A significantly greater share of women, compared to men, reported symptoms in all body parts except in low back and knees at both workplaces. Good general health was reported by $80 \%$ of both men and women but men in male dominated workplaces perceived significantly better psychological well-being than the others.

Conclusions: Women and men in this region performed different work tasks and a greater share of women than men reported musculoskeletal symptoms. This was the fact also when working in the same type of segregated workplaces.
\end{abstract}

Keywords: Gender segregated, musculoskeletal symptoms, organisation, work environment.

\section{INTRODUCTION}

Heavy physical load at work is a potential risk factor for many different diseases, such as cardiovascular and musculoskeletal diseases [1-3]. Psychosocial job strain is often associated with musculoskeletal symptoms [4-8]. Environments with high chemical-physical exposures are often found in combination with heavy physical workload and an association with musculoskeletal symptoms is obvious [9-11].

Literature reviews indicate that women in general report less musculoskeletal well-being than men [12]. One reason could be the gender segregated labour market. Men and women work in different sectors - or more precisely, with different work tasks. So far, most attention has been focussed on occupational risk factors such as physically heavy and demanding exposures like manual materials handling, dust and noise, i.e. environments typical for male workers. This type of exposures often put more emphasis on whole-body exertions and energy expenditure than on local, repetitive stress to the upper extremities. Job requiring high static loading of the neck and shoulders, with repetitive use of small muscle groups, involve a high risk of upper extremity disorders. During dynamic low-load manual work, the higher the speed of motion and/or the higher the precision demands are the more increased muscle forces relative to capacity are needed $[13,14]$.

Address correspondence to this author at the Department of health sciences, Luleå University of Technology, SE-971 87 Luleå, Sweden; Tel: +46 72 5390645; E-mail: Lena.Karlqvist@ltu.se
The physical demands of female-intensive jobs are often perceived by those not performing the jobs to be less strenuous than the jobs typically performed by men. Women and men working in the same factories, with the same job titles did not always perform tasks with the same physical requirements or work organisation [15]. Women performed more repetitive work on average, whereas men were less likely to sit for prolonged periods, compared to women. Exposures relevant to the occurrence of musculoskeletal disorders include both physical workload and the organisation of work in general [15]. There is scientific evidence of cause-and-effect relationships between repetitive motion, forceful work, and postural stress for disorders of the back and upper extremities [13]. The risk is particularly high when two or more of these features are simultaneous and exert synergistic effects [13].

Being a female is often described as a "risk factor" for many musculoskeletal disorders because prevalence in the general population and in large groups of employees has reported to be twice as high among women compared to men $[16,17]$. As Punnett and Herbert [15] point out, it is essential to distinguish between genders differences in crude prevalence or risk and differences in the effects of occupational exposures on musculoskeletal outcome. The associations of musculoskeletal disorders with gender and occupational ergonomic exposures should be assessed separately in order to determine whether women are at increased risk when exposed to the same ergonomic stresses as men. 


\section{OBJECTIVE}

The aim of this study was to investigate the associations of ergonomic exposures with musculoskeletal disorders and more specifically to see how differences between men and women in terms of working conditions, musculoskeletal symptoms, general health and psychological well-being were related to workplaces segregated by gender.

What were the differences between men and women, at workplaces, dominated by men and women, respectively?

What were the differences among men and among women at the gender segregated workplaces?

These research questions were the focus of this study.

\section{MATERIAL AND METHODS}

\section{Region and Study Context}

The Norrköping region and the neighbouring municipalities of Finspång and Söderköping were selected as the study region. This is rather a well demarcated region in Sweden with a flow of labour between these municipalities, although each municipality has its own economic structure and social and cultural context. There are also a number of gender segregated workplaces suited for this research project. We were also met by a positive attitude from politicians and decision makers to development of equal opportunities and to cooperation between practice and research. Introductory conferences were held early in order to identify questions and problems with respect to working conditions at the segregated workplaces with a focus on the ergonomic conditions to promote the development and change on local and regional level within the municipalities.

Norrköping has traditionally been a pronounced trading- and industrial city dominated by textile-, paper- and manufacturing industry, but has developed the business sector. The University of Linköping has a Campus Norrköping which has improved the development positively with growth for knowledge based and technical qualified businesses. Norrköping has approximately 122000 inhabitants. Finspång has a long tradition as an industrial community. Occupations within the industry are as high as 46 percent. The labor market is highly gender segregated. Within the industry, 65 percent of the men and 20 percent of the women are occupied. Women are mostly occupied within the health sector, 40 percent where only 4 percent of the men are found. The number of inhabitants has steadily decreased and is now about 22000 . Young people move out and there is a lack of a qualified engineers and workers. Söderköping is a smaller municipal, 14000 inhabitants. Small businesses are common.

\section{Study Population}

A questionnaire was sent to a randomly selected group of 10000 persons, aged 18-64 years living in the region. The response rate was $50 \%$ (4965 men and women). They were asked about the distribution of gender at their workplace. Those working at gender segregated workplaces (most women, $\geq 60 \%$ women or most men, $\geq 60 \%$ men) constituted the study group. Twenty percent of the men and $25 \%$ of the women, who had answered the questionnaire, did not fulfil the criteria for the analysis in the present study (no paid jobs, on sick-leave $>3$ months, students, etc) and were excluded. Data of respondents is shown in Table $\mathbf{1}$.

We used a modified classification system developed by Kohn and Schooler [18], where occupations were categorised in three groups: In the "people" category are occupations where the person mainly work with people - for example nurse, dentist, teacher or cashier. In the"things" category the person mainly works with objects - for example construction worker, cleaner or cook. In the "data" category,

Table 1. Characteristics of Respondents with and without Paid Jobs

\begin{tabular}{|c|c|c|c|c|c|c|}
\hline & \multicolumn{3}{|c|}{ Men } & \multicolumn{3}{|c|}{ Women } \\
\hline & $\mathbf{n}$ & $\%$ & Mean Age & $\mathbf{n}$ & $\%$ & Mean Age \\
\hline Respondents without paid jobs, on sick-leave $>3$ months, students, etc. & 456 & 20 & - & 684 & 25 & - \\
\hline Workplaces with most women $(\geq 60 \%)$ & 227 & 10 & $40(18-62)$ & 1487 & 54 & $43(18-62)$ \\
\hline Workplaces with about the same distribution of men and women (40-60\%) & 300 & 14 & $41(18-62)$ & 307 & 11 & $39(18-62)$ \\
\hline Workplaces with most men $(\geq 60 \%)$ & 1236 & 56 & $42(18-62)$ & 268 & 10 & $40(18-62)$ \\
\hline Total & 2219 & 100 & - & 2746 & 100 & - \\
\hline
\end{tabular}

Table 2. Gender Segregated Workplaces and Relative Frequency of Men and Women Working with "People", "Thing" and "Data"

\begin{tabular}{|c|c|c|c|c|c|c|c|c|}
\hline & \multicolumn{4}{|c|}{ Men } & \multicolumn{4}{|c|}{ Women } \\
\hline & \multirow[t]{2}{*}{$\mathbf{n}$} & People & Thing & Data & \multirow[t]{2}{*}{$\mathbf{n}$} & People & Thing & Data \\
\hline & & $\%$ & $\%$ & $\%$ & & $\%$ & $\%$ & $\%$ \\
\hline \multicolumn{9}{|c|}{ Most Women } \\
\hline$(\geq 60 \%)$ & 227 & 52 & 28 & 20 & 1487 & 70 & 16 & 14 \\
\hline \multicolumn{9}{|c|}{ Most Men } \\
\hline$(\geq 60 \%)$ & 1236 & 5 & 78 & 17 & 268 & 10 & 69 & 21 \\
\hline
\end{tabular}


data formed the main object - for example journalist, secretary, computer operator or engineer (Table 2).

In female dominated workplaces both men and women worked predominantly in the "people" category; $52 \%$ of the men and $70 \%$ of the women. In male dominated workplaces both men and women worked predominantly in the "data" category; $78 \%$ of the men and $69 \%$ of the women.

\section{METHODS}

\section{Questionnaire}

A comprehensive questionnaire was sent to the participants. Standardised, reliable and valid questions were used [19], which made it possible to compare with other relevant studies in the area. The questionnaire included a wide range of questions on health and physical and psychosocial risk factors at work as well as on background data, employment/unemployment, physical and chemical and psychosocial working conditions, work organisation, general health, musculoskeletal symptoms and psychological wellbeing.

Questions on work organisation included employer, gender distribution, work hours, negative changes in working conditions during the last 12 months, negative expectation of the future and work flexibility, in total eighteen questions with $3-8$ answer alternatives.

Questions on physical work exposure were focussed on known risk factors for developing musculoskeletal symptoms. Exposure questions on duration in different work postures and manual materials handling were measured on a scale from 0 to 10 or by selecting one of five alternatives: not at all, 1-3 days/month, 1 day/week, 2-4 days/ week, every day.

Questions on psychosocial work exposure were derived from the demand-control-social support model [20].

A single question measuring general health was derived from the SF36 questionnaire [21, 22]: How would you rate your health in general at present? Five response alternatives were given: excellent, very good, good, fair and poor. Those given the response alternative excellent, very good and good were included in the analysis.

Questions measuring musculoskeletal symptoms were derived from the Nordic Questionnaire [23]. Nine different body parts were illustrated by a figure and those who marked any symptoms during the last three months were included in the analysis.

Questions measuring general psychological well-being were derived from the SF36 questionnaire [21, 22]. Answers to nine questions were reported on a six-graded scale about feelings during the last four weeks. The scale ranged from "all the time" to "not at all during this time period". An index of the nine questions was created and ranged from 9 to 54.

\section{Data Analysis}

Cross tables were used to calculate relative frequency of women and men at the gender segregated workplaces exposed to physical, psychosocial and organisational risk factors at work. Questions with more than two response alternatives were dichotomised at the $75^{\text {th }}$ percentile. Only those with high exposures $\left(\geq 75^{\text {th }}\right.$ percentile) were included in the analysis.

Logistic regression analysis was conducted to calculate odds ratios (OR) and 95\% confidence intervals, OR $(95 \%$ CI), for risk indicators of musculoskeletal symptoms associated with exposures at gender segregated workplaces. Men in female dominated workplaces were used as a reference group $(\mathrm{OR}=1)$. Gender and segregated workplaces were included in the same model.

Relative frequencies of women and men at the segregated workplaces were compared regarding organisational working condition, psychosocial exposures and physical exposures as well as general health, psychological well-being and musculoskeletal symptoms. The difference between men and women (M-W) and among men and among women in prevalence of symptoms and exposures was expressed in difference between proportions with $95 \%$ confidence intervals [24]. Differences were statistically significant when $\mathrm{CI}>1$ or $\mathrm{CI}<-1$.

All statistical analyses were performed with the SPSS program

\section{RESULTS}

\section{Did the Working Conditions Differ Significantly Between Men and Women in Female and Male Dominated Workplaces?}

There were differences in working conditions between men and women both in female and male dominated workplaces (Table 3). Two organisational factors (part-time work and negative expectation of the future) differed between men and women (more prevalent among women) in female dominated workplaces (Table 3). Five organisational factors differed between men and women in male dominated workplaces (Table 3). Two psychosocial work environment factors (low control and strain) differed and were more prevalent among women in male dominated workplaces. As many as eleven physical work environment factors differed between men and women in female dominated workplaces and there were higher frequency of women in five of these factors; stationary standing posture, moving around at work, manual materials handling in the two lowest weight classes and high physical exertion experienced at ordinary work. In male dominated workplaces, there was a higher frequency of women in four factors (sedentary work, computer usage, VDU-screen usage and repetitive hand/finger tasks) while men were more frequent in 11 factors (Table $\mathbf{3}$ ).

The following differences showed to be significant in the analysed data among men and among women in gender segregated workplaces (Table 4):

- Both men and women in female dominated workplaces showed higher frequencies of part-time work, while both men and women in male dominated workplaces showed higher frequencies of salaries only by piecework.

- $\quad$ More men in female dominated workplaces perceived high work demands compared to men in male dominated workplaces.

- More women in male dominated workplaces perceived low control and low support from 
Table 3. Significant Differences in Working Conditions Between Men and Women in Female and Male Dominated Workplaces. The Relative Frequency (\%) of Men and Women, Differences with 95\% Confidence Interval (CI). Grey Area Indicates Significant Differences

\begin{tabular}{|c|c|c|c|c|c|c|}
\hline Working Conditions & \multicolumn{2}{|c|}{ Most Women ( $\geq 60 \%$ ) } & \multicolumn{4}{|c|}{ Most Men ( $\geq 60 \%)$} \\
\hline No possibility to stay home for shorter illness & 59 & 59 & $0(-7-7)$ & 58 & 65 & $-7(-13--1)$ \\
\hline Part-time work $\leq 30$ hours/week & 14 & 35 & $-21(-26--16)$ & 5 & 18 & $-13(-18--8)$ \\
\hline Inconvenient working hours & 7 & 9 & $-2(-6-2)$ & 13 & 8 & $5(1-9)$ \\
\hline Unsafe employment & 19 & 19 & $0(-6-6)$ & 19 & 25 & $-6(-11--0.1)$ \\
\hline Negative xpectation of the future & 22 & 29 & $-7(-13--1)$ & 20 & 25 & $-5(-10-5)$ \\
\hline \multicolumn{7}{|l|}{ Psychosocial work environment } \\
\hline \multicolumn{7}{|l|}{ Physical work environment } \\
\hline Sedentary work & 35 & 23 & $12(5-18)$ & 29 & 51 & $-22(-29--16)$ \\
\hline Computer usage & 39 & 30 & $9(2-16)$ & 35 & 60 & $-25(-32--19)$ \\
\hline VDU-screen usage & 32 & 26 & $6(-0.3-13)$ & 28 & 55 & $-27(-33--20)$ \\
\hline Stationary (standing) posture & 20 & 27 & $-7(-13--2)$ & 12 & 13 & $-1(-6-3)$ \\
\hline Moving around at work & 26 & 36 & $-10(-16--4)$ & 33 & 19 & $14(9-19)$ \\
\hline Bounded sitting at work & 35 & 24 & $11(4-17)$ & 28 & 34 & $-6(-12-0.2)$ \\
\hline Working on vibrating surface & 7 & 3 & $4(1-7)$ & 37 & 16 & $21(16-26)$ \\
\hline Manual material handling, $5-15 \mathrm{~kg}$ & 26 & 34 & $-8(-14--2)$ & 48 & 22 & $26(20-32)$ \\
\hline Manual material handling, above $15 \mathrm{~kg}$ & 27 & 33 & $-6(-1-0.1)$ & 45 & 17 & $28(22-33)$ \\
\hline High physical exertion experienced at ordinary work & 16 & 34 & $-18(-24--13)$ & 31 & 19 & $12(7-17)$ \\
\hline
\end{tabular}

colleagues compared to women in female dominated workplaces.

- Two physical work environment factors with high exposures had more men in female dominated workplaces compared to men in male dominated workplaces (stationary standing posture and bounded sitting).

- $\quad$ Twelve other physical work environment factors with high exposures had more men in male dominated workplaces compared to men in female dominated workplaces.

- Among women, there was a more even distribution of work environment factors in differences between female (eight factors) and male (seven factors) dominated workplaces (Table 4).

Did the Musculoskeletal Symptom Panorama Differ in Men and Women in Female and Male Dominated Workplaces?

Self-reported musculoskeletal symptoms differed between men and women in the gender segregated groups. A higher frequency of women, compared to men, reported symptoms in all body parts except in low back and knees in female dominated workplaces (Table 5). In male dominated workplaces, the picture was similar. More men; however, reported symptoms in knees (Table 5).

Differences in symptom reports among men in female and male dominated workplaces and women in female and 
Table 4. Significant Differences in Working Conditions Between Men in Male Dominated Workplaces and Men in Female Dominated Workplaces As Well As Women in Female Dominated Workplaces and Women in Male Dominated Workplaces. The Relative Frequency (\%) of Men and Women, Differences with 95\% Confidence Interval (CI). Grey Area Indicates Significant Differences

\begin{tabular}{|c|c|c|c|c|c|c|}
\hline Working Conditions & $\begin{array}{c}\text { Men } \\
\geq \mathbf{6 0 \%} \text { Women } \\
\mathbf{N}=\mathbf{2 2 7}\end{array}$ & $\begin{array}{c}\text { Men } \\
\geq \mathbf{6 0 \%} \text { Men } \\
\mathrm{N}=\mathbf{1 2 3 6}\end{array}$ & $\begin{array}{l}\text { Men/Men } \\
\text { Difference }\end{array}$ & $\begin{array}{c}\text { Women } \\
\geq \mathbf{6 0 \%} \text { Women } \\
\mathrm{N}=\mathbf{1 4 8 7}\end{array}$ & $\begin{array}{c}\text { Women } \\
\geq \mathbf{6 0 \%} \% \text { Men } \\
\mathrm{N}=\mathbf{2 6 8}\end{array}$ & $\begin{array}{c}\text { Women/Women } \\
\text { Difference }\end{array}$ \\
\hline Organisation & $\%$ & $\%$ & $\%(\mathrm{CI})$ & $\%$ & $\%$ & $\%(\mathrm{CI})$ \\
\hline No possibility to adjust work tasks to the form of the day & 12 & 17 & $-5(-10-0.4)$ & 13 & 17 & $-4(-9-1)$ \\
\hline Part-time work $\leq 30$ hours/week & 14 & 5 & $9(4-14)$ & 35 & 18 & $17(12-22)$ \\
\hline Salary only by achievement & 8 & 26 & $-18(-22-14)$ & 8 & 13 & $-5(-9-0.7)$ \\
\hline Inconvenient working hours & 7 & 13 & $-6(-10-2)$ & 9 & 8 & $1(-2-5)$ \\
\hline Unsafe employment & 19 & 19 & $0(-6-6)$ & 19 & 25 & $-6(-11-0.1)$ \\
\hline \multicolumn{7}{|l|}{ Psychosocial work environment } \\
\hline High demands & 41 & 30 & $11(4-18)$ & 37 & 32 & $5(-1-11)$ \\
\hline Low control & 24 & 26 & $-2(-9-4)$ & 26 & 35 & $-9(-14--1)$ \\
\hline Low support from colleagues & 26 & 30 & $-4(-10-2)$ & 20 & 29 & $-8(-14--2)$ \\
\hline \multicolumn{7}{|l|}{ Physical work environment } \\
\hline Sedentary work & 35 & 29 & $6(-1-13)$ & 23 & 51 & $-28(-35--22)$ \\
\hline Computer usage & 39 & 35 & $4(-3-11)$ & 30 & 60 & $-30(-36--24)$ \\
\hline VDU-screen usage & 32 & 28 & $4(-2-11)$ & 26 & 55 & $-29(-35--23)$ \\
\hline Stationary (standing) posture & 20 & 12 & $8(2-13)$ & 27 & 13 & $14(9-19)$ \\
\hline Moving around at work & 26 & 33 & $-7(-13--1)$ & 36 & 19 & $17(12-22)$ \\
\hline Bounded sitting at work & 35 & 28 & $7(0.1-14)$ & 24 & 34 & $-10(-16--4)$ \\
\hline Working on vibrating surface & 7 & 37 & $-30(-34--26)$ & 3 & 16 & $-13(-18--9)$ \\
\hline Working with vibrating tools & 14 & 46 & $-32(-37--27)$ & 6 & 13 & $-7(-11--3)$ \\
\hline Precision work & 14 & 20 & $-6(-11--0.8)$ & 8 & 9 & $-1(-5-3)$ \\
\hline Working with hands above shoulders & 17 & 35 & $-18(-23--12)$ & 22 & 16 & $6(1-11)$ \\
\hline Working with hands below knee levels & 16 & 36 & $-20(-26--15)$ & 19 & 15 & $1(-4-6)$ \\
\hline Bending/twisting posture & 47 & 58 & $-11(-18--4)$ & 54 & 52 & $2(-4-9)$ \\
\hline Repetitive hand/finger tasks & 29 & 30 & $-1(-7-6)$ & 31 & 56 & $-25(-31--19)$ \\
\hline Manual material handling, $1-5 \mathrm{~kg}$ & 39 & 51 & $-12(-19--5)$ & 49 & 41 & $8(2-14)$ \\
\hline Manual material handling, $5-15 \mathrm{~kg}$ & 26 & 48 & $-22(-28--16)$ & 34 & 22 & $12(7-18)$ \\
\hline Manual material handling, above $15 \mathrm{~kg}$ & 27 & 45 & $-18(-25--12)$ & 33 & 17 & $16(11-21)$ \\
\hline High physical exertion experienced at ordinary work & 16 & 31 & $-15(-21--10)$ & 34 & 19 & $15(10-20)$ \\
\hline
\end{tabular}

male dominated workplaces were less than between men and women in female and male dominated workplaces (Table 6). More men in male dominated workplaces reported symptoms in elbows, knees and feet/ankles than men in female dominated workplaces. More females in female dominated workplaces reported symptoms in hands/wrists (Table 6).

Associations of musculoskeletal health split on gender and segregated workplaces with men in female dominated workplaces as reference group $(\mathrm{OR}=1)$ was calculated (Table 7).
Did the General Health and Psychological Well-Being Differ Between Men and Women in Female and Male Dominated Workplaces?

No significant difference in general health was noted between men and women in female and male dominated workplaces. Excellent, very good or good general health was reported by $80 \%$ of the men in female dominated workplaces and by $77 \%$ of the women. In male dominated workplaces the frequencies were 83 and $81 \%$ respectively (Table 8 ).

The mean values of psychological well-being were 39.6 and 39.4 for men and women in female dominated workplaces and 42.2 and 39.3 for men and women in male dominated workplaces. Men in male dominated workplaces 
Table 5. Significant Differences in Musculoskeletal Symptoms Reported by Men and Women in Female and Male Dominated Workplaces and Differences Between Men and Women with 95\% Confidence Interval (CI). Grey Area Indicates Significant Differences

\begin{tabular}{|c|c|c|c|c|c|c|}
\hline & \multicolumn{3}{|c|}{ Most Women ( $\geq 60 \%)$} & \multicolumn{3}{|c|}{ Most Men ( $\geq 60 \%$ ) } \\
\hline & $\begin{array}{c}\text { Men } \\
\text { N=227 }\end{array}$ & $\begin{array}{l}\text { Women } \\
N=1487\end{array}$ & $\begin{array}{c}\text { Men/Women } \\
\text { Difference }\end{array}$ & $\begin{array}{c}\text { Men } \\
\mathrm{N}=1236\end{array}$ & $\begin{array}{l}\text { Women } \\
N=268\end{array}$ & $\begin{array}{c}\text { Men/Women } \\
\text { Difference }\end{array}$ \\
\hline Body part & $\%$ & $\%$ & $\%(\mathrm{CI})$ & $\%$ & $\%$ & $\%(\mathrm{CI})$ \\
\hline Any symptom & 67 & 82 & $-15(-22--9)$ & 73 & 81 & $-8(-13--3)$ \\
\hline Neck & 47 & 58 & $-11(-19--2)$ & 42 & 61 & $-19(-26--11)$ \\
\hline Shoulders & 27 & 42 & $-15(-23--8)$ & 26 & 45 & $-19(-27--12)$ \\
\hline Elbows & 2 & 7 & $-5(-7--2)$ & 6 & 7 & $-1(-3-3)$ \\
\hline Hands/wrists & 7 & 18 & $-12(-16--7)$ & 10 & 13 & $-3(-8-2)$ \\
\hline Upper back & 17 & 24 & $-7(-14--1)$ & 15 & 22 & $-7(-13--1)$ \\
\hline Hips & 11 & 24 & $-12(-18--7)$ & 14 & 25 & $-11(-17--5)$ \\
\hline Knees & 25 & 27 & $-2(-10-5)$ & 38 & 25 & $13(7-20)$ \\
\hline Feet/ankles & 11 & 22 & $-10(-16--4)$ & 21 & 21 & $-0.03(-4-8)$ \\
\hline
\end{tabular}

Table 6. Significant Differences in Musculoskeletal Symptoms Between Men in Male Dominated Workplaces and Men in Female Dominated Workplaces As Well As Women in Female Dominated Workplaces and Women in Male Dominated Workplaces. The Relative Frequency (\%) of Men and Women, Differences with 95\% Confidence Interval (CI). Grey Area Indicates Significant Differences

\begin{tabular}{|c|c|c|c|c|c|c|}
\hline & $\begin{array}{c}\text { Men } \\
\geq \mathbf{6 0 \%} \text { Women } \\
\mathbf{N}=\mathbf{2 2 7}\end{array}$ & $\begin{array}{c}\text { Men } \\
\geq \mathbf{6 0 \%} \% \text { Men } \\
\mathrm{N}=1236\end{array}$ & $\begin{array}{l}\text { Men/Men } \\
\text { Difference }\end{array}$ & $\begin{array}{c}\text { Women } \\
\geq \mathbf{6 0 \%} \text { Women } \\
\mathrm{N}=\mathbf{1 4 8 7}\end{array}$ & $\begin{array}{c}\text { Women } \\
\geq \mathbf{6 0 \%} \% \text { Men } \\
\text { N=268 }\end{array}$ & $\begin{array}{c}\text { Women/Women } \\
\text { Difference }\end{array}$ \\
\hline Body part & $\%$ & $\%$ & $\%(\mathrm{CI})$ & $\%$ & $\%$ & $\%(\mathrm{CI})$ \\
\hline Elbows & 2 & 6 & $-4(-6--1)$ & 7 & 7 & $1(-2-4)$ \\
\hline Hands/wrists & 7 & 10 & $-3(-8-1)$ & 18 & 13 & $6(0.7-11)$ \\
\hline Knees & 25 & 38 & $-13(-21--6)$ & 27 & 25 & $2(-4-9)$ \\
\hline Feet/ankles & 11 & 21 & $-9(-15--3)$ & 22 & 21 & $1(-5-7)$ \\
\hline
\end{tabular}

were found to have the best psychological well-being. When calculating the relative frequency for men and women in female- and male dominated workplaces with well-being representing at least "a lot of the time" in the index we found; $65 \%$ of the men and $67 \%$ of the women in female dominated workplaces and $80 \%$ of the men and $63 \%$ of the women in male dominated workplaces. Men in male dominated workplaces experienced significantly better psychological well-being than their female contra parts as well as men and women in female dominated workplaces (Table 8).

\section{DISCUSSION}

Women, compared to men, had higher prevalence in two organisational factors; part-time work and negative expectation of the future and eleven physical environment factors, which concerned working postures, movements, and materials handling in female dominated workplaces. Women, compared to men, also had higher prevalence in three organisational factors and two psychosocial factors; low control and high strain in male dominated workplaces. Today, part-time work is still prevalent in female dominated work together with negative expectations for future development in work. We consider it possible that the women in this study want to work full time but not having the opportunity to do so. Hence, their negative expectations may be ascribed to low decision latitude, lack of social support and high psychosocial job demands. This has earlier been shown to characterize female repetitive manual jobs [15]. Our results confirm that men and women perceive different ergonomic workload. It has been shown that women working in high-intensive jobs with high static loading of the upper extremity, repetitive movements and high precision demands are having a high risk for musculoskeletal disorders [13, 14]. However, women and men in this study with the same job titles did not necessarily work with tasks with the same physical requirements or work organisation. The fact that the women perceived lower control and higher strain compared to men in male dominated workplaces can be ascribed to the fact that they may perform more repetitive work compared to the men, which also has been confirmed in earlier research [15]. Women may also have work tasks with higher physical workload [15]. So, the gender differences in male dominated 
Table 7. Odds Ratios (OR) and 95\% Confidence Interval (CI) of Self-Reported Musculoskeletal Symptoms in Men and Women in Gender Segregated Workplaces with Men in Female Dominated Workplaces as Reference Group. Grey Area Indicates Significant Differences of Symptoms

\begin{tabular}{|c|c|c|c|c|c|c|c|c|}
\hline Any symptom & 1 & - & 1.3 & $0.97-1.78$ & 2.3 & $1.70-3.13$ & 2.0 & $1.35-3.07$ \\
\hline Neck & 1 & - & 0.8 & $0.59-1.18$ & 1.5 & $1.10-2.17$ & 1.8 & $1.17-2.71$ \\
\hline Elbows & 1 & - & 3.1 & $0.95-9.85$ & 4.3 & $1.34-13.6$ & 3.5 & $0.97-12.4$ \\
\hline Hands/wrists & 1 & - & 1.6 & $0.79-3.07$ & 3.2 & $1.63-6.08$ & 2.0 & $0.96-4.35$ \\
\hline Upper back & 1 & - & 0.9 & $0.54-1.35$ & 1.5 & $0.99-2.40$ & 1.4 & $0.80-2.31$ \\
\hline Low back & 1 & - & 1.0 & $0.73-1.45$ & 1.2 & $0.83-1.63$ & 1.0 & $0.69-1.59$ \\
\hline
\end{tabular}

Table 8. Well-Being Reported by Men in Female and Male Dominated Workplaces and Women in Female and Male Dominated Workplaces as Well as Between Men and Women in Female and Male Dominated Workplaces. The Relative Frequency (\%) of Men and Women, Respectively, and Differences with 95\% Confidence Interval (CI). Grey Area Indicates Significant Differences of General Health and Psychological Well-Being

\begin{tabular}{|c|c|c|c|c|c|c|}
\hline & $\begin{array}{c}\text { Men } \\
\geq \mathbf{6 0 \%} \text { Women } \\
\text { N=227 }\end{array}$ & $\begin{array}{c}\text { Men } \\
\geq \mathbf{6 0 \%} \text { Men } \\
\mathrm{N}=\mathbf{1 2 3 6}\end{array}$ & $\begin{array}{l}\text { Men/Men } \\
\text { Difference }\end{array}$ & $\begin{array}{c}\text { Women } \\
\geq \mathbf{6 0 \%} \text { Women } \\
\mathrm{N}=\mathbf{1 4 8 7}\end{array}$ & $\begin{array}{l}\text { Women } \\
\geq \mathbf{6 0 \%} \% \text { Men } \\
\mathrm{N}=\mathbf{2 6 8}\end{array}$ & $\begin{array}{l}\text { Women/Women } \\
\text { Difference }\end{array}$ \\
\hline General Health & 80 & 83 & $-3(-8-3)$ & 77 & 81 & $-4(-9-1)$ \\
\hline Psychological well-being & 65 & 80 & $-15(-21-8)$ & 67 & 63 & $-4(-2-10)$ \\
\hline
\end{tabular}

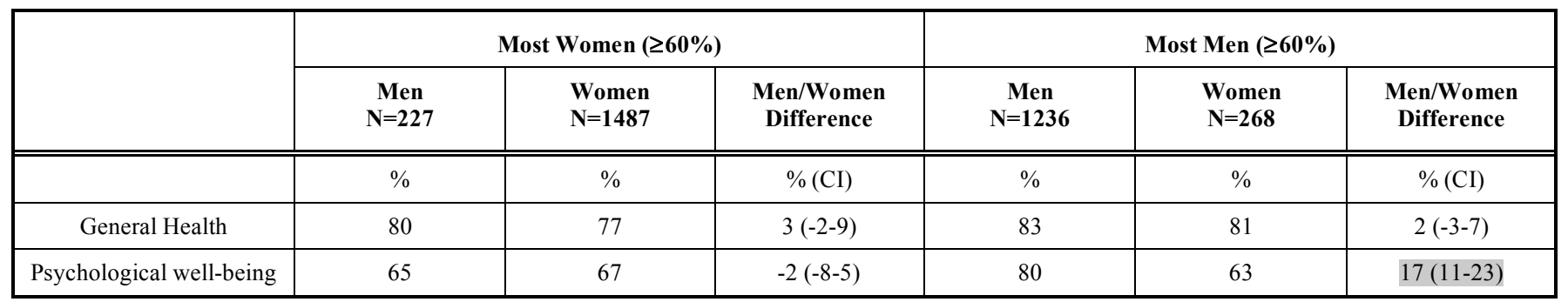

workplaces may be ascribed to a higher level of repetitive movements, physical strain, and postural stress among the women, which in earlier studies have been confirmed to have harmful effects when combined [13]. A higher frequency of musculoskeletal symptoms was shown among women compared to men, in most body parts, at both female and male dominated workplaces. This was the fact also when working in the same type of segregated workplace. It is reasonable to believe that the result concerning musculoskeletal symptoms could be understood according to differences in work tasks and level of repetitive work.

Concerning physical working conditions, the results show gender differences in crude prevalence or risk. However, it is not clear if there are real differences in the effects of occupational exposures on the musculoskeletal outcome. We believe that the real exposures may differ even in the same work position between women and men. In future studies, exposure differences in work performed by women and men respectively should be further explored from a gender perspective. According to the results in this study, tailored interventions for women at these workplaces according to their occupational exposure patterns are needed. Different tailored interventions may be needed. Women with high physical strain may benefit from a greater variety in work and less repetitive work tasks, women with high psychosocial strain may need interventions focusing how to obtain flexibility and increased job control. 
We suggest that the results from this study, concerning all relevant ergonomic, psychosocial and organisational factors, should be considered when planning future tailored interventions, particularly for women. By doing so, the high risk for women, to develop musculoskeletal disorders can be reduced. We consider this as a policy recommendation, which is also important from a gender perspective.

In addition, we recommend further health promoting work at these workplaces to maintain the level of general health. Earlier research has shown that health promoting interventions can maintain work ability and build up worker strengths, competencies and resources $[25,26]$. We consider health promoting activities as a policy recommendation which can further increase the workers job satisfaction and well-being.

This study shows good general health reported by about $80 \%$ of both men and women in all workplaces studied. Psychological well-being differed most in male dominated workplaces, where the men $(80 \%)$ reported the best wellbeing. Hence, the work organisation can be characterised as a healthy work organisation. However, from a total working environment perspective the results seem a bit contradictory as this study shows gender differences in crude prevalence of ergonomic risks but at the same time a good general health and fairly good psychological well-being, especially among men in male dominated workplaces.

\section{Methodological Considerations}

Dropout analysis showed that non-respondents were not randomly distributed. More elderly than young, more women than men, more high-educated than low-educated and more ethnic Swedes than immigrants responded to the questionnaire. With the support of statistical expertise, using the method RHG, Response Homogeneity Group [27], weights for sub-groups were created in order to compensate for the uneven response rate. These created weights were used in the analyses, but since they did not change the results in this study in any significant way they are not presented.

A comprehensive questionnaire with standardised, reliable and valid questions was used [19]. The questions with more than two response alternatives were dichotomised at the $75^{\text {th }}$ percentile and compared men and women only with those who had high exposures ( $\geq 75^{\text {th }}$ percentile).

Logistic regression analysis was conducted to calculate odds ratios (OR) and 95\% confidence intervals, OR $(95 \%$ $\mathrm{CI}$ ), for risk indicators of musculoskeletal symptoms associated with exposures at gender segregated workplaces. This method is frequently used within occupational medicine.

The difference between men and women in prevalence of symptoms and exposures was expressed in difference between proportions with $95 \%$ confidence intervals according to Gardner \& Altman [24]. Differences were statistically significant when $\mathrm{CI}>1$ or $\mathrm{CI}<-1$.

\section{CONCLUDING REMARKS}

Women and men perform different work tasks and have different working conditions in gender segregated work places. Gender differences in crude prevalence of ergonomic risks were shown and will be used for the development of work and health promoting activities at these workplaces. At the same time a good general health and fairly good psychological well-being, especially among men in male dominated workplaces, were shown.

We recommend tailored interventions for women according to their occupational exposure patterns.

In addition, programs that emphasise the ergonomic design of workstations, equipment, tools, and work organisation to fit the capabilities and limitations of the human worker are needed.

\section{ACKNOWLEDGEMENTS}

Declared none.

\section{CONFLICT OF INTEREST}

Declared none.

\section{REFERENCES}

[1] Hagberg M. Exposure variables in ergonomic epidemiology. Am J Ind Med 1992; 21: 91-100.

[2] Winkel J, Westgaard R. Occupational and individual risk factors for shoulder-neck complaints: Part II. The scientific basis for the guide [review]. Int J Ind Ergon 1992; 10: 85-104.

[3] Hallqvist J, Moller J, Ahlbom A, Diderichsen F, Reuterwall C, de Faire U. Does heavy physical exertion trigger myocardial infarction? A case-crossover analysis nested in a population-based case-referent study. Am J Epidemiol 2000; 151(5): 459-67.

[4] Bongers PM, de Winter CR, Kompier MAJ, Hildebrandt VH. Psychosocial factors at work and musculoskeletal disease. Scand J Work Environ Health 1993; 19: 297-312.

[5] Josephson M, Gustafsson H, Ahlberg-Hultén G, et al. Differences in the association between psychosocial work conditions and physical work load in female- and male-dominated occupations. Am Ind Hyg Assoc J 1999; 60: 673-8.

[6] Hoogendoorn WE, van Poppel MNM, Bongers PM, Koes BW, Bouter LM. Physical load during work and leisure time as risk factors for back pain [review]. Scand J Work Environ Health 1999; 25(5): 387-403.

[7] Devereux J, Buckle P. The risk of neck, shoulder and upper-limb musculoskeletal disorders due to interactions between physical and psychosocial work risk factors. In: Program and abstract book, International Ergonomics Association XIVth Triennial Congress and Human Factors and Ergonomics Society 44th Annual Meeting; July 29-August 4. San Diego: California, USA 2000.

[8] Ariëns GAM, van Mechelen W, Bongers PM, Bouter LM, van der Wal G. Physical risk factors for neck pain [review]. Scand J Work Environ Health 2000; 26: 7-19.

[9] Hagberg M, Silverstein B, Wells R, et al. Work related musculoskeletal disorders (WMSDs). In: Kuorinka I, Forcier L, Eds. A reference book for prevention. London: Taylor \& Francis 1995.

[10] Kjellberg A. Subjectives behavioral and psychophysiological effects of noise. Scand J Work Environ Health 1990; 16(Suppl 1): 29-38.

[11] Kjellberg A, Sköldström B, Tesaiz M. Equal EMG response levels to a 100 and $1000 \mathrm{~Hz}$ tone. Proc Internoise 1991; 91: 847-50.

[12] de Zwart B, Frings-Dresden M, Kilbom Å. Gender differences in upper extremity musculoskeletal complaints in the working population. Int Arch Occup Environ Health 2001; 74(1): 21-30.

[13] Bernard BP, Ed. musculoskeletal disorders and workplace factors. a critical review of epidemiological evidence for work-related musculoskeletal disorders of the neck, upper extremity, and low back. Cincinatti: National Institute for Occupational Safety and Health 1997.

[14] Sjøgaard G, Sjøgaard K. Musculoskeletal disorders and the workplace: low back and upper extremities. National Academies Press: USA 1998.

[15] Punnett L, Herbert R. Work-related musculoskeletal disorders: Is there a gender difference - So what does it mean? Women and Health. In: Goldman MB, Hatch M, Eds. San Diego CA; Academic Press 2000: pp. 474-92. 
[16] Viikari-Juntura E, Vuori J, Silverstein B, Kuosma E, Videman T. A life-long prospective study on the role of psychosocial factors in neck-shoulder and low-back pain. Spine 1991; 16(9): 1056-61.

[17] de Zwart BC, Broersen JP, Frings-Dresen MH, van Dijk FJ. Musculoskeletal complaints in The Netherlands in relation to age, gender and physically demanding work. Int Arch Occup Environ Health 1997; 70(5): 352-60.

[18] Kohn ML, Schooler C, Miller J. Work and personality: An inquairy into the impact of social stratification. Ablex Public Corporation Norwood, NJ 1983.

[19] Härenstam A, Bodin L, Karlqvist L, et al. Patterns of working and living conditions: a holistic, multivariate approach to occupational health studies. Work Stress 2003; 17: 1 .

[20] Karasek R, Theorell T. Healthy Work - Stress, Productivity, and the Reconstruction of Working Life. New York: Basic Books Inc. 1990.

[21] Brazier JE, Harper R, Jones NM, et al. Validating the SF-36 health survey questionnaire: new outcome measure for primary care. BMJ 1992; 305: 160-4.
[22] Goldberg D, Williams PA. User's Guide to the General Health Questionnaire. NFER- Nelson: Windsor 1998.

[23] Kuorinka I, Jonsson B, Kilbom Å, et al. Standarised Nordic questionnaires for the analysis of musculoskeletal symptoms. Appl Ergonom 1987; 18(3): 233-7.

[24] Gardner MJ, Altman DG, Eds. Statistics with confidence Confidence intervals and statistical guidelines. Br Med J (British Medical Asscociation) Tavistock Square, London WCIH 9JR. London 1989.

[25] Shain M, Kramer DM. Health promotion in the workplace: framing the concept; reviewing the evidence. Occup Environ Med 2004; 61: 643-8.

[26] Gard G. Work motivation - a brief review of theories underpinning health promotion. Phys Ther Rev 2002; 7: 167-72.

[27] Sarndal CE, Swensson B, Wretman J. Model assisted survey sampling. New York: Springer-Verlag New York Inc. 1992.

(C) Karlqvist and Gard; Licensee Bentham Open.

This is an open access article licensed under the terms of the Creative Commons Attribution Non-Commercial License (http: //creativecommons.org/licenses/ by-nc/3.0/) which permits unrestricted, non-commercial use, distribution and reproduction in any medium, provided the work is properly cited. 